\title{
GELATIN PRODUCTION FROM SKIN OF CHICKEN LEG USING A VARIETY OF NAOH CONCENTRATION
}

\author{
Rety Setyawaty ${ }^{1)}$ May Triliandari ${ }^{1)}$ \\ 1) Pharmacy Academy of Kusuma Husada Purwokerto, Gang Anggrek, Berkoh, Purwokerto Selatan, Sokawera, \\ Berkoh, Purwokerto Sel., Kabupaten Banyumas, Jawa Tengah 53146 \\ Email : rety.setyawaty@gmail.com
}

Diterima 4 Oktober 2018; diterima pasca revisi 31 Oktober 2018

Layak diterbitkan 31 Oktober 2018

\begin{abstract}
Gelatin is a type of protein that is extracted from collagen of skin, bone, or ligament (animal connective tissue) tissue. Cow bone, cowhide and pig skin are the materials commonly used to obtain gelatin. The purpose of this research was to determine the difference of $\mathrm{NaOH}$ concentration as soaking agent on gelatin making from skin of chicken leg (Gallus gallus domesticus) for 72 hours of soaking. Fresh skin of chicken leg weighing $250 \mathrm{~g}$ were immersed in $\mathrm{NaOH}$ solution with concentrations of 1\%, 1.5\%, and $3 \%$ for 72 hours, then extracted using n-hexane solution: alcohols in a ratio of 1: 3 and dried to obtain gelatin. The resulting gelatin is then analyzed for physicochemical characteristics such as sensory, yield, $p H$ test, and water content test. The results of this study, mentioned that the concentration of $1 \% \mathrm{NaOH}$ solution produces gelatin under average of yield of $6 \mathrm{~g}$, neutral $\mathrm{pH}$ and water content of $11 \%$. The concentration of $1.5 \% \mathrm{NaOH}$ solution produces gelatin under average of yield $8 \mathrm{~g}, \mathrm{pH} 7$ and water content of 13\%. The concentration of $3 \% \mathrm{NaOH}$ solution produces gelatin under average of yield $4.144 \mathrm{~g}, \mathrm{pH} 7$ and water content of $7.11 \%$. Based on the result, it can be concluded that a good solution of $\mathrm{NaOH}$ to get high yield under a concentration of $1.5 \%$ solution. The gelatin obtained under $1.5 \%$ solution in accordance with the standard gelatin. The characteristics of standard gelatin are colorless to yellow, odorless, tasteless, pH 7 (neutral), and moisture content below $16 \%$.
\end{abstract}

Key words : Gelatin; gallus gallus domesticus; soaking agent; physicochemical properties 


\begin{abstract}
ABSTRAK
Gelatin merupakan jenis dari protein yang diekstrak dari kolagen jaringan kulit, tulang atau jaringan ligamen (jaringan konektif ternak). Kulit tulang sapi, kulit sapi dan babi adalah bahan yang biasa digunakan untuk mendapatkan gelatin. Tujuan penelitian ini adalah untuk mengetahui perbedaan konsentrasi $\mathrm{NaOH}$ sebagai perendaman pada pembuatan gelatin dari kulit kaki ayam (Gallus gallus domesticus) yang direndam selama 72 jam. Kulit kaki ayam seberat $250 \mathrm{~g}$ direndam dalam larutan $\mathrm{NaOH}$ dengan konsentrasi $1 \%$, 1,5\%, dan 3\% selama 72 jam, kemudian diekstraksi menggunakan larutan n-heksana: alkohol dengan perbandingan 1: 3, kemudian dikeringkan hingga menghasilkan gelatin. Gelatin yang dihasilkan kemudian dianalisis untuk karakteristik fisikokimia seperti uji organoleptik, uji pH, dan uji kadar air. Hasil penelitian ini menunjukkan bahwa konsentrasi larutan $\mathrm{NaOH} 1 \%$ menghasilkan gelatin di bawah rata-rata hasil $6 \mathrm{~g}$, $\mathrm{pH}$ netral dan kadar air $11 \%$. Konsentrasi larutan $\mathrm{NaOH} \mathrm{1,5 \%} \mathrm{menghasilkan} \mathrm{gelatin} \mathrm{di} \mathrm{bawah} \mathrm{rata-rata} \mathrm{hasil} 8 \mathrm{~g}$, pH 7 dan kadar air 13\%. Konsentrasi larutan NaOH 3\% menghasilkan gelatin di bawah rata-rata hasil 4,144 g, pH 7 dan kadar air 7,11\%. Dapat disimpulkan bahwa larutan NaOH yang baik untuk mendapatkan hasil yang tinggi di bawah konsentrasi larutan 1,5\% karena sesuai dengan gelatin standar. Karakteristik gelatin standar tidak berwarna hingga kuning, tidak berbau, tidak berasa, pH 7 (netral), dan kadar air di bawah 16\%.
\end{abstract}

Kata kunci : Gelatin; gallus gallus domesticus; larutan perendaman; sifat fisikokimia

\section{INTRODUCTION}

Gelatin is a natural product obtained through partial hydrolysis of collagen from animal skin and bones (Duconseille et al., 2015; Etxabide et al., 2015). Utilization of gelatin is very widely. It is estimated that around $59 \%$ of gelatin produced worldwide is used for the food industry, $31 \%$ for the pharmaceutical industry, $2 \%$ for the photography industry, and around $8 \%$ for other industries (Mohebi and Shahbazi, 2017). So far, Indonesia's gelatin needs have been imported from several countries such as France, Japan, India, Brazil, Germany, China, Argentina and Australia (BPS, 2015). Gelatin imports in 2014 reached $255,822 \mathrm{~kg}$ with a value of US \$ 2,059,329 (BPS, 2015).

One important aspect that needs to be considered is the halalness for Muslims. Kuan et al. (2016) states that $98.5 \%$ of gelatin in the world is produced from meat, bone and pork skin, therefore it is necessary to develop gelatin production from other animal sources. Previous research has produced gelatin production technology from bovine bones (Yuniarifin et al., 2006), fish bones (Marzuki et al., 2011), fish skin (Shyni et al., 2014), chicken skin (Sarbon et al., 2013), sheepskin (Hasdar and Rahmawati, 2017), chicken feet (Rafieian et al., 2015), and duck legs (Kuan et al., 2016).

Another example of this research is Haryati (2011) which is making gelatin from skin of chicken leg which is applied as a gelling agent in making multivitamin jelly candy. Chicken leg, is one of the results found in the Chicken Slaughterhouse. Its potential is abundant along with the high number of chicken cuts.

The number of broiler cuts in Indonesia in 2011 was 1.3 million tons $(1.3$ million $\mathrm{x} 103 \mathrm{~kg})$. Due to the large number of chicken leg produced, it is quite
*Corresponding author :

Rety Setyawaty

Email : rety.setyawaty@gmail.com

Pharmacy Academy of Kusuma Husada Purwokerto, Gang Anggrek, Berkoh, Purwokerto Selatan, Sokawera, Berkoh, Purwokerto Sel., Kabupaten Banyumas, Jawa Tengah 53146
How to cite :

Setyawati, R., \& Triliandari, M. (2018). Gelatin Production from Skin of Chicken Leg using A Variety of Naoh Concentration. Jurnal Ilmu dan Teknologi Hasil Ternak, 13 (2), 126-132 
potential as a raw material in the manufacture of processed products that have a selling value.

One of the products that use raw material skin of chicken leg is gelatin. Chicken leg skin has collagen, which results in hydrolysis of the collagen will produce gelatin.

This study was conducted to determine the yield under $\mathrm{NaOH}$ concentration of $1 \%, 1.5 \%$ and $3 \%$ as a soaking media in making gelatin from skin of chicken leg (Gallus gallusdomesticus) by using soaking time for 72 hours in term of physicochemical.

\section{MATERIALS AND METHODS}

\section{Sample selection procedures}

Skin of chicken leg (Gallus gallus domesticus) was obtained from one traditional market in Purwokerto.

\section{Materials}

The materials are skin of chicken leg from broiler variety, technical $\mathrm{NaOH} 1 \mathrm{M}$ with concentrations of $1 \%, 1.5 \%$ and $3 \%$, then extracted using technical n-hexane, and $96 \%$ of ethanol.

\section{Procedure}

\section{Collection of chicken leg skin from} broiler chicken variety

Skin of chicken leg used in this study was obtained from the Chicken Slaughterhouse in a Purwokerto traditional market.

\section{Separation of skin from chicken leg}

The leg of broiler chicken as much as 9 $\mathrm{kg}$ is skinned in the right way. The plug from fresh broiler chicken is washed with cold water until clean, then proceed with cutting the finger on the base except the middle finger. Furthermore, the skin is sliced straight on the back of the leg from the base of the foot to the tip of the finger, the skin is peeled with a knife, and the carried meat is cleaned with a knife. Then the skin is washed with water until it is clean and weighed to find out the yield obtained (Purnomo, 1992).

\section{Soaking in bases}

$2 \mathrm{~g}$ of $\mathrm{NaOH}$ Preparation of $1 \% \mathrm{NaOH}$ solution by $2 \mathrm{~g} \mathrm{NaOH}$ was dissolved in $200 \mathrm{~mL}$ of aquadest. Preparation of $1.5 \% \mathrm{NaOH}$ solution by $3 \mathrm{~g}$ of $\mathrm{NaOH}$ dissolved in $200 \mathrm{~mL}$ of aquadest. Preparation of $3 \% \mathrm{NaOH}$ solution by $6 \mathrm{~g}$ $\mathrm{NaOH}$ was dissolved in $200 \mathrm{~mL}$ of aquadest. Skin of chicken leg as much as $250 \mathrm{~g}$ for each $\mathrm{NaOH}$ concentration soaked for 72 hours while occasionally stirring.

\section{Neutralization}

Skin of chicken leg is obtained from soaking in $\mathrm{NaOH}$ under different of concentration, then separated from $\mathrm{NaOH}$ solution by washing using flowing water.

\section{Extraction and heating}

Skin of chicken leg was soaked in technical chemical n-hexane : ethanol under ratio 1 : 3 for an hour. Furthermore, it is heated in a waterbath under temperature $70-90 \mathrm{oC}$ for one hour. The results of heating process are then filtered and the filtrate is taken.

\section{Gelatin molding}

Gelatin solution was poured in a mold. Then storage in the room temperature. After that, storage in for one day at $50 \mathrm{oC}$ in oven.

\section{Drying of gelatin}

The cooled and hardened gelatin was removed from the mold and then dried in a drying cabinet at $50 \mathrm{oC}$ until the moisture content is less than $16 \%$ for 48 hours.

\section{Gelatin powder}

Gelatin was blender until it becomes powder. 


\section{Packaging}

Powder gelatin is stored in a plastic.

\section{Physico-chemical analaysis}

Analysis of gelatin produced from the skin of chicken leg, such as sensory test, yield, $\mathrm{pH}$ and moisture content.

\section{Statistical analysis}

Data obtained from the results of subsequent studies analyzed by one-way analysis of variance (ANOVA) and if there is any significant difference then continued by test using Duncan's Multiple Range Test (DMRT) at the 5\% significance level $(\alpha=$ $0.05)$ with SPSS for Windows version 16.

\section{RESULTS AND DISSCUSION}

\section{Sensory test of gelatin}

Sensory tests include form, taste, color, and smell. The resulting gelatin has a powder form, the taste of chicken feet is not strong, pale yellow to colorless, and non-stinging smell, both fishy smell from chicken feet or odor from solvents. The test results obtained were compared with the existing gelatin standard in Indonesian Pharmacopoeia and SNI (Indonesian National Standard). In Indonesian Pharmacopoeia, the description of gelatin is in the form of sheets, chips, powders or granules, colorless or pale yellow, smell and weak taste (MOH, 1979). In SNI -01$3735-1995$ it is stated that the quality requirements for gelatin are colorless to pale yellowish, normal odor and taste. Based on the Indonesian Pharmacopoeia and SNI standards it can be concluded that the gelatin produced meets the requirements, in accordance with the Pharmacopoeia and SNI -01-3735-1995. Organoletic test results can be seen in Table 1.

Table 1. Sensory test of gelatin

\begin{tabular}{|c|c|c|c|c|c|}
\hline \multirow{2}{*}{$\begin{array}{c}\mathrm{NaOH} \\
\text { concentration }(\%)\end{array}$} & \multirow{2}{*}{$\begin{array}{l}\text { Soaking } \\
\text { time } \\
\text { (hour) }\end{array}$} & \multirow[b]{2}{*}{ Sample } & \multicolumn{3}{|c|}{ Results } \\
\hline & & & Color intensity & Taste & Odor \\
\hline \multirow{3}{*}{$1 \%$} & \multirow{9}{*}{72 hours } & 1 & Yellow & Neutral & Fishy \\
\hline & & 2 & Yellow & Neutral & Fishy \\
\hline & & 3 & Yellow & Neutral & Fishy \\
\hline \multirow{3}{*}{$1.5 \%$} & & 1 & Dark Yellow & Neutral & Fishy \\
\hline & & 2 & Dark Yellow & Neutral & Fishy \\
\hline & & 3 & Dark Yellow & Neutral & Fishy \\
\hline \multirow{3}{*}{$3 \%$} & & 1 & Pale Yellow & Neutral & Fishy \\
\hline & & 2 & Pale Yellow & Neutral & Fishy \\
\hline & & 3 & Pale Yellow & Neutral & Fishy \\
\hline
\end{tabular}

$\mathrm{NaOH}$ solution obtained from the rest of soaking of the chicken feet skin has a cloudy color. This shows the occurrence of deproteinization process on the skin of chicken feet. Deproteinase or non-collagen protein removal in chicken feet skin is caused by $\mathrm{NaOH}$ solution which is able to break down most of the collagen molecular telopeptides in the pre treatment process so that swelling occurs on the skin of chicken feet (Jaswir et al, 2011). In the treatment using $1 \% \mathrm{NaOH}$ solution, light yellow color was obtained. This is because the $1 \%$ $\mathrm{NaOH}$ solution dissolves non-collagen protein, while collagen protein remains stuck in the skin so that the resulting color intensity looks faded. In the treatment using $3 \% \mathrm{NaOH}$ solution significantly dissolves collagen and non collagen proteins so that the color becomes pale due to the large 
amount of collagen protein dissolved in $\mathrm{NaOH}$ solution. Whereas in the treatment using $\mathrm{NaOH}$ solution with a concentration of $1.5 \%$ there was a perfect deproteinization process so that the resulting color became more concentrated.

\section{Yield}

The yield is one of the important parameters in making gelatine. Efficient and effective extraction process of raw materials for making gelatine can be seen from the yield value produced. The greater the yield is produced, the more efficient the treatment is given (Said et al, 2011). The yield was calculated based on the comparison of the gelatine powder produced with the fresh chicken leg skin used. The yield can be seen in Table 2 and Table 3.

Table 2. Yield of gelatine (\%)

\begin{tabular}{ccccc}
\hline \multirow{2}{*}{$\mathrm{NaOH}$ concentration } & \multirow{2}{*}{$\begin{array}{c}\text { Soaking time } \\
\text { (hour) }\end{array}$} & \multicolumn{3}{c}{ Yield (\%) } \\
\cline { 3 - 5 } & & 1 & 2 & 3 \\
\hline $1 \%$ & \multirow{2}{*}{72 hours } & 5.88 & 5.80 & 5.86 \\
\cline { 4 - 5 } & & 7.97 & 8.00 & 7.96 \\
\cline { 4 - 5 } & & 4.14 & 4.14 & 4.15 \\
\hline $3 \%$ & & &
\end{tabular}

Table 3. Yield of gelatin $(\mathrm{g})$

\begin{tabular}{ccccc}
\hline \multirow{2}{*}{$\mathrm{NaOH}$ concentration } & \multirow{2}{*}{$\begin{array}{c}\text { Soaking time } \\
\text { (hour) }\end{array}$} & \multicolumn{3}{c}{ Yield $(\mathrm{g})$} \\
\cline { 3 - 5 } & & 1 & 2 & 3 \\
\hline $1 \%$ & \multirow{2}{*}{72 hours } & 14.70 & 14.52 & 14.66 \\
\cline { 4 - 5 } & & 19.92 & 20.01 & 19.90 \\
\cline { 4 - 5 } & & 10.35 & 10.36 & 10.39 \\
\hline
\end{tabular}

The yield of gelatin with $1 \% \mathrm{NaOH}$ concentration can dissolve non-collagen protein without causing collagen loss in the skin, so the yield obtained is less than that of gelatin soaked in $\mathrm{NaOH}$ solution with a concentration of $1.5 \%$. Whereas, the use of $3 \% \mathrm{NaOH}$ solution is significantly caused collagen loss in the skin during the pretreatment process, resulting in lower yield rates. The treatment of $\mathrm{NaOH}$ with a concentration of $1.5 \%$ allows collagen to have completely dissolved to obtain a higher yield (Liu et al, 2015).

\section{pH}

$\mathrm{pH}$ value is one important parameter of gelatin quality. The $\mathrm{pH}$ value will affect other gelatin properties such as viscosity, gel strength, and melting point. Gelatin with neutral $\mathrm{pH}$, its use will be wider because it is more stable (Astawan, 2002). The $\mathrm{pH}$ of gelatin can be seen in Table 4 .

Table 4. The $\mathrm{pH}$ value of gelatin

\begin{tabular}{|c|c|c|c|c|}
\hline \multirow{2}{*}{$\mathrm{NaOH}$ concentration } & \multirow{2}{*}{$\begin{array}{c}\text { Soaking } \\
\text { time (hour) }\end{array}$} & \multicolumn{3}{|c|}{$\mathrm{pH}$ value } \\
\hline & & 1 & 2 & 3 \\
\hline $1 \%$ & \multirow{3}{*}{72 hours } & 7 & 7 & 7 \\
\hline $1.5 \%$ & & 7 & 7 & 7 \\
\hline $3 \%$ & & 7 & 7 & 7 \\
\hline
\end{tabular}

The $\mathrm{pH}$ of the gelatin obtained is neutral, which means that the gelatin produced has met the requirements. The $\mathrm{pH}$ value of gelatin is very dependent on the stage of the washing process. Optimal washing can remove the soaking solution $(\mathrm{NaOH})$. This is necessary because alkaline solutions can cause further hydrolysis and reduced quality of gelatin. 


\section{Moisture content}

Water is an important ingredient in food. The role of water in foodstuffs is influencing in metabolic processes such as enzyme activity, microbial activity, chemical activity, namely the occurrence of rancidity and non-enzymatic reactions that cause changes in organoleptic properties and nutritional value (Astawan, 2002).

Determination of water content is to determine the water content contained in gelatin. The water content in gelatin will greatly affect the storage power due to its relation to metabolic reactions that occur during the gelatin stored (Setiawati, 2009).

Based on the requirements according to the Indonesian National Standard or SNI, the maximum gelatin moisture content is $16 \%$. While the gelatin requirements according to FAO, gelatin water content is not more than $18 \%$. The results of the water content analysis of gelatin from chicken feet skin extract can be seen in Table 5 .

Table 5. Water content of gelatin

\begin{tabular}{|c|c|c|c|c|}
\hline \multirow{2}{*}{$\mathrm{NaOH}$ concentration } & \multirow{2}{*}{$\begin{array}{l}\text { Soaking time } \\
\text { (hour) }\end{array}$} & \multicolumn{3}{|c|}{ Water content (\%) } \\
\hline & & 1 & 2 & 3 \\
\hline $1 \%$ & & 8.5 & 12.2 & 12.2 \\
\hline $1.5 \%$ & 72 hours & 13 & 14.5 & 11.3 \\
\hline $3 \%$ & & 8.3 & 7.03 & 6.03 \\
\hline
\end{tabular}

The range of moisture content of chicken feet skin extract gelatin from 3 types of $\mathrm{NaOH}$ concentration as a soaking liquid is $6.03 \%-14.53 \%$. This value is still in the range of water content permitted by the Indonesian National Standard (SNI, 1995) for gelatine which is a maximum of $16 \%$ and FAO requirements (JECFA, 2003) may not exceed $18 \%$.

\section{CONCLUSION}

The test results of physical and chemical characteristics of gelatin of chicken feet skin extract stated that a good soaking solution was a $\mathrm{NaOH}$ solution with a concentration of $1.5 \%$. This is because the $\mathrm{NaOH}$ with a concentration of $1.5 \%$ allows collagen to dissolve completely to obtain a higher yield. In addition, the value of acidity $(\mathrm{pH})$, water content and sensory test of gelatin extract of chicken skin with $1.5 \%$ $\mathrm{NaOH}$ solution has been in accordance with the requirements stipulated in the SNI and FAO even though the value of the obtained water content is quite high.

\section{REFERENCES}

Astawan, M., Hariyadi, P., \& Mulyani, A. (2002). Analisis sifat reologi gelatin dari kulit ikan cucut. Jurnal Teknologi Dan Industri Pangan, 13, 38-46.

BPS. (2015). Statistik Perdagangan Luar Negeri (Vol. 38425). Jakarta: Badan Pusat Statistik.

Duconseille, A., Astruc, T., Quintana, N., Meersman, F., \& Sante-Lhoutellier, V. (2015). Gelatin structure and composition linked to hard capsule dissolution: A review. Food Hydrocolloids, 43, 360-376. https://doi.org/10.1016/J.FOODHYD.2014.06.006

Etxabide, A., Urdanpilleta, M., Guerrero, P., \& de la Caba, K. (2015). Effects of cross-linking in nanostructure and physicochemical properties of fish gelatins for bio-applications. Reactive and Functional Polymers, 94, 55-62. https://doi.org/10.1016/J.REACTFUNCTPOLYM.2015.07.006 
Haryati, T. (2011). Formulasi Permen Jelly Multivitamin dengan Gelatin Kulit Ceker Ayam sebagai Bahan Pembentuk Gel. Universitas Muhammadiyah Purwokerto.

Hasdar, M., \& Rahmawati, Y. D. (2017). Kajian potensi kulit domba asal brebes sebagai bahan dasar produksi gelatin halal. Jurnal Aplikasi Teknologi Pangan, 6(1), 1-6. https://doi.org/10.17728/jatp.211

Irwandi Jaswir, I., Monsur, H., \& Salleh, H. (2011). Nano-structural analysis of fish collagen extracts for new process development. African Journal of Biotechnology, 10(81), 18847-18854. https://doi.org/10.5897/AJB11.2764

Kuan, Y.-H., Nafchi, A. M., Huda, N., Ariffin, F., \& Karim, A. A. (2016). Effects of sugars on the gelation kinetics and texture of duck feet gelatin. Food Hydrocolloids, 58, 267275. https://doi.org/10.1016/J.FOODHYD.2016.02.025

Liu, D., Nikoo, M., Boran, G., Zhou, P., \& Regenstein, J. M. (2015). Collagen and gelatin. annual Review of Food Science and Technology, 6(1), 527-557. https://doi.org/10.1146/annurev-food-031414-111800

Marzuki, A., Pakki, E., \& Zulfikar, F. (2011). Ekstraksi dan penggunaan gelatin dari limbah tulang ikan bandeng (Chanos Chanos Forskal) sebagai emulgator dalam formulasi sediaan emulsi. Majalah Farmasi Dan Farmakologi, 15, 63-68.

Mhd Sarbon, N., Badii, F., \& Howell, N. K. (2013). Preparation and characterisation of chicken skin gelatin as an alternative to mammalian gelatin. Food Hydrocolloids, 30(1), 143-151. https://doi.org/10.1016/J.FOODHYD.2012.05.009
Mohebi, E., \& Shahbazi, Y. (2017). Application of chitosan and gelatin based active packaging films for peeled shrimp preservation: A novel functional wrapping design. LWT Food Science and Technology, 76, 108116. https://doi.org/10.1016/J.LWT.2016.10.062

Rafieian, F., Keramat, J., \& Shahedi, M. (2015). Physicochemical properties of gelatin extracted from chicken deboner residue. LWT - Food Science and Technology, 64(2), 1370-1375. https://doi.org/10.1016/J.LWT.2015.04.050

Said, M. I., Triatmojo, S., Erwanto, Y., \& Fudholi, A. (2012). Karakteristik gelatin kulit kambing yang diproduksi melalui proses asam dan basa. Agritech, 31(3), 190-200. https://doi.org/10.22146/AGRITECH.9744

Setiawati, I. H. (2009). Karakteristik Mutu Fisika Kimia Gelatin Kulit Ikan Kakap Merah (Lutjanus sp.) Hasil Proses Perlakukan Asam. Fakultas Perikanan dan Ilmu Kelautan Institut Pertanian Bogor.

Shyni, K., Hema, G., Ninan, G., Mathew, S., Joshy, C. G., \& Lakshmanan, P. T. (2014). Isolation and characterization of gelatin from the skins of skipjack tuna (Katsuwonus pelamis), dog shark (Scoliodon sorrakowah), and rohu (Labeo rohita). Food Hydrocolloids, $\quad 39, \quad 68-76$. https://doi.org/10.1016/J.FOODHYD.2013.12.008

Yuniarifin, H., Bintoro, V. P., \& Suwarastuti, A. (2006). Pengaruh berbagai konsentrasi asam fosfat pada proses perendaman tulang sapi terhadap rendemen, kadar abu dan viskositas gelatin. J. Indonesian Trop. Anim. Agric, 31, 55-61. 